\title{
DESTRUCTION OF THE RECEPTOR SUBSTANCE FOR PYOCIN R BY A LIVER EXTRACT OF TURBO CORNUTUS ${ }^{1}$
}

\author{
YOSHIKAZU KUROSAWA, ${ }^{2}$ KAYOKO IKEDA, ${ }^{3}$ \\ AND FUJIO EGAMI ${ }^{4}$ \\ Department of Biophysics and Biochemistry, Faculty of Science, \\ University of Tokyo, Hongo, Tokyo 113
}

(Received March 29, 1973)

\begin{abstract}
1) Liver extract of a marine gastropod, Turbo cornutus, destroyed the pyocin-R receptor activity of the lipopolysaccharide of sensitive Pseudomonas aeruginosa.

2) The extract contained at least two factors, probably proteins, attacking the receptor; one attacking below $\mathrm{pH} 4$ inactivated the receptor immediately and the other with optimum $\mathrm{pH} 6.2$ inactivated the receptor gradually. The latter was partially purified and its properties are described. It was strongly inactivated by acetate buffer.
\end{abstract}

Pyocin R, a bacteriocin produced by Pseudomonas aeruginosa $\mathrm{P} 15$, can be adsorbed by the lipopolysaccharide obtained from the strains of $P$. aeruginosa sensitive to the pyocin. Therefore, the lipopolysaccharide is regarded as a receptor substance for pyocin $\mathrm{R}(1)$.

In order to know the nature of the specific receptor site on the lipopolysaccharide, effect of a liver extract of a marine gastropod, Turbo cornutus, on the lipopolysaccharide was investigated. The extract is known to be rich in digestive enzymes including different glycosidases $(2-5)$, and it has indeed been found that the receptor can be inactivated by the liver extract. Although the chemical mechanism of the inactivation has not been elucidated, the

1 This constitutes Part IV of a series entitled "Studies on receptor substance for pyocin R" (Parts I, II, III : References 1, 15, 16). A part of this study was presented at the 44th Annual Meeting of the Japanese Biochemical Society on October 7, 1971, at Sendai.

2 Present address: Institute of Molecular Biology, Faculty of Science, Nagoya University, Chikusa-ku, Nagoya 464.

3 Present address: Department of Neuropharmacology, Brain Research Institute, Niigata University, Niigata 951.

4 Present address: Mitsubishi-Kasei Institute of Life Sciences, 11 Minamiooya, Machida, Tokyo 194. 
present paper describes the phenomena, and the properties and partial purification of a receptor-destroying factor in the liver extract.

\section{MATERIALS AND METHODS}

Bacterial strains. Pseudomonas aeruginosa $\mathrm{P} 14$, pyocin R-sensitive strain, was used for preparation of the receptor (1). P. aeruginosa $\mathrm{P} 15$, pyocinogenic strain, was used for the preparation of pyocin $\mathrm{R}(1)$.

Bacterial culture. The culture medium contained $10 \mathrm{~g}$ of polypeptone (Daigo Eiyo Co., Osaka), $10 \mathrm{~g}$ of meat extract (Kyokuto Seiyaku Co., Tokyo), and $1 \mathrm{~g}$ of $\mathrm{NaCl}$ in 1 liter of distilled water. The $\mathrm{pH}$ of the medium was adjusted to 7.0 with $1 \mathrm{~N} \mathrm{NaOH}$.

Pyocin. Pyocin R was prepared from a Mitomycin-C-induced lysate of $P$. aeruginosa P15 by the method of KAGEYAMA ( 6$)$.

Lipopolysaccharide. Lipopolysaccharide was isolated by the phenol extraction method of WESTPHAL ( 7$)$. The preparation was further freed from ribonucleic acids by treatment with pancreatic RNase ( 8 ).

Other materials. DEAE-cellulose and Sephadex G-200 were products of Brown and Pharmacia, respectively.

Preparation of crude liver extract. All procedures were carried out at $0^{\circ}$ to $5^{\circ}$.

Step 1. Two hundred and fifty grams of the liver of Turbo cornutus was homogenized in a Waring blender with 1 liter of $1 \mathrm{M} \mathrm{NaCl}$ solution for $5 \mathrm{~min}$ at $0^{\circ}$. After centrifugation for $40 \mathrm{~min}$ at $5,000 \times \mathrm{g}$, the supernatant was brought to $30 \%$ saturation with $\left(\mathrm{NH}_{4}\right)_{2} \mathrm{SO}_{4}$. After being stood for $1 \mathrm{hr}$, the precipitate was removed by centrifugation for $40 \mathrm{~min}$ at $5,000 \times g$.

Step 2. The supernatant was brought to $70 \%$ saturation with $\left(\mathrm{NH}_{4}\right)_{2} \mathrm{SO}_{4}$, stood for $4 \mathrm{hr}$, and centrifuged for $60 \mathrm{~min}$ at $5,000 \times g$. The precipitate was dissolved in $150 \mathrm{ml}$ of water and dialyzed against distilled water.

Step 3. This solution was then dialyzed against $0.05 \mathrm{M}$ acetate buffer, $\mathrm{pH} 4.0$, overnight and the resulting precipitate was removed by centrifugation at $5,000 \times g$ for $40 \mathrm{~min}$.

Step 4. This supernatant was further fractionated by $\left(\mathrm{NH}_{4}\right)_{2} \mathrm{SO}_{4}$ at $30 \%$ and $70 \%$ saturations. The fraction obtained between these two saturations was collected, dialyzed against water, and concentrated to $215 \mathrm{ml}$ by dialysis against polyethyleneglycol. The concentrated solution was stored at $0^{\circ}$ as a crude extract.

Assay of receptor activity. Receptor activity was assayed as described previously ( 1 ).

Assay of receptor-destroying activity. The reaction mixture was composed of $0.1 \mathrm{ml}$ of $0.05 \mathrm{M}$ citrate-phosphate buffer, $\mathrm{pH} 6.2$, containing $0.5 \%$ lipopolysaccharide and $0.1 \mathrm{ml}$ of the solution to be assayed. Fifty microliters of the reaction mixture was taken off at time zero and after incubation for $24 \mathrm{hr}$ at $37^{\circ}$, and the remaining receptor activity was measured. 


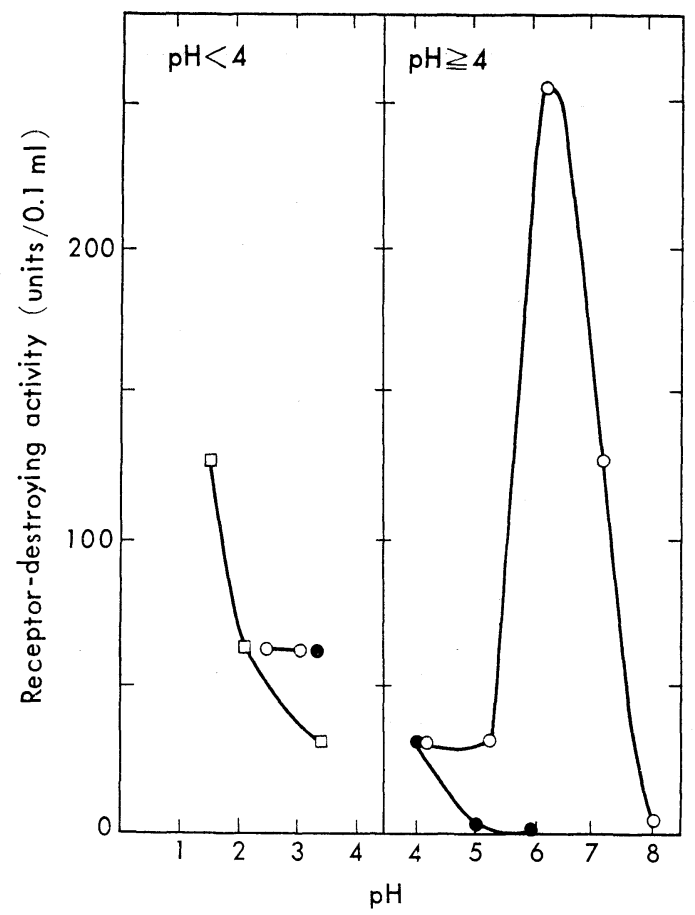

Fig. 1. $\mathrm{pH}$ Dependency of the crude extract.

- $\bigcirc-, 0.025 \mathrm{M}$ citrate phosphate buffer; - - $-0.05 \mathrm{M}$ acetate buffer;

$-\square-, 0.05 \mathrm{M} \mathrm{HCl-glycine} \mathrm{buffer}$.

Receptor-destroying activity was expressed as the ratio of the receptor activity before incubation to that after incubation. For example the initial receptor activity was usually 320 and the remaining activity was 10 , then the receptor-destroying activity was estimated as 32 units.

\section{RESULTS}

\section{$p H$ Dependence of receptor-destroying activity}

The effect of $\mathrm{pH}$ on the destruction of the receptor activity of lipopolysaccharide by the crude extract is shown in Fig. 1. Receptor-destroying factor showed quite a different behavior in its inactivation kinetics above and below $\mathrm{pH} 4$.

As shown in Fig. 2, below $\mathrm{pH} 4$ the receptor activity of lipopolysaccharide decreased immediately by the addition of the preparation, and the activity could not be recovered at higher $\mathrm{pH}$. The degree of this irreversible inactivation was apparently stoichiometric, i.e., proportional to the quantity of the extract added. Although the mechanism of this destruction remains to be elucidated, it may not be an enzymic process. 
(A)

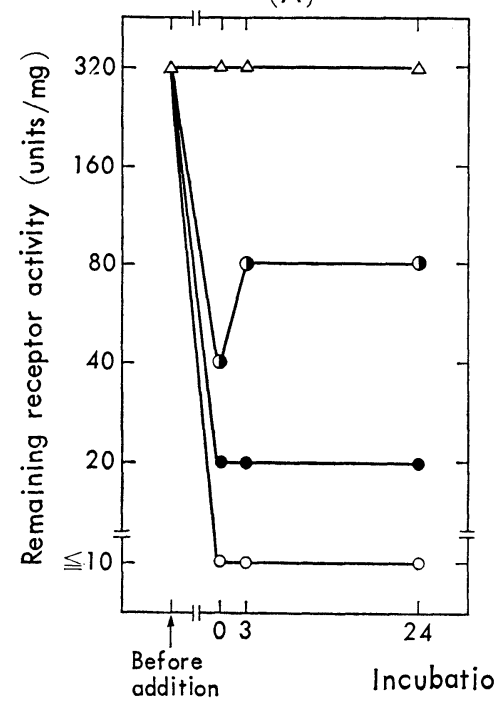

(B)

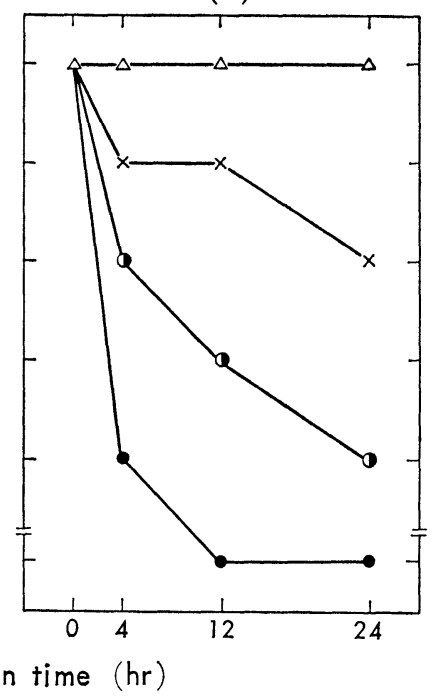

Fig. 2. Time course of inactivation of receptor substance by the crude extract of Turbo cornutus in HCl-glycine buffer ( $\mathrm{pH} 2.0$ ) and citrate-phosphate buffer ( $\mathrm{pH}$ $6.2)$.

Lipopolysaccharide was incubated with the diluted liver extract as described in "Assay of receptor-destroying activity," (A) in $0.05 \mathrm{M} \mathrm{HCl-glycine} \mathrm{buffer} \mathrm{(pH} \mathrm{2.0)} \mathrm{and}$ (B) in $0.025 \mathrm{M}$ citrate phosphate buffer ( $\mathrm{pH} 6.2$ ). After incubated for the indicated periods, remaining receptor activity was assayed. Relative concentration of the crude extract: $-\triangle-$, Buffer only; $-\bigcirc-, 1 ;-\bullet-, 1 / 2 ;-\rightarrow-, 1 / 4 ;-\times-, 1 / 8$.

On the contrary, above $\mathrm{pH} 4.0$, there was no immediate decrease of activity. The receptor activity decreased with time and the rate of this inactivation was proportional to the amount of the extract. Therefore, this process may be regarded as an enzymic one. The activity had its optimum at pH 6.2 with citrate buffer, and it was inhibited by acetate buffer.

\section{Heat stability of receptor-destroying factor}

Heat stability of the receptor-destroying factor in the crude extract is shown in Fig. 3. The activity decreased on heating at $60^{\circ}$ so that the activity may be due to a substance of protein nature.

\section{Sephadex G-200 column chromatography}

The crude extract was concentrated to $50 \mathrm{ml}$ by Diaflo, and applied on a column $(5 \times 95 \mathrm{~cm})$ of Sephadex G-200, which had been equilibrated with 0.01 $\mathrm{M} \mathrm{NaCl}$ solution. Effluent was collected in $10-\mathrm{ml}$ fractions (Fig. 4). The receptor-destroying activity at $\mathrm{pH} 6.2$ was assayed for each fraction. 


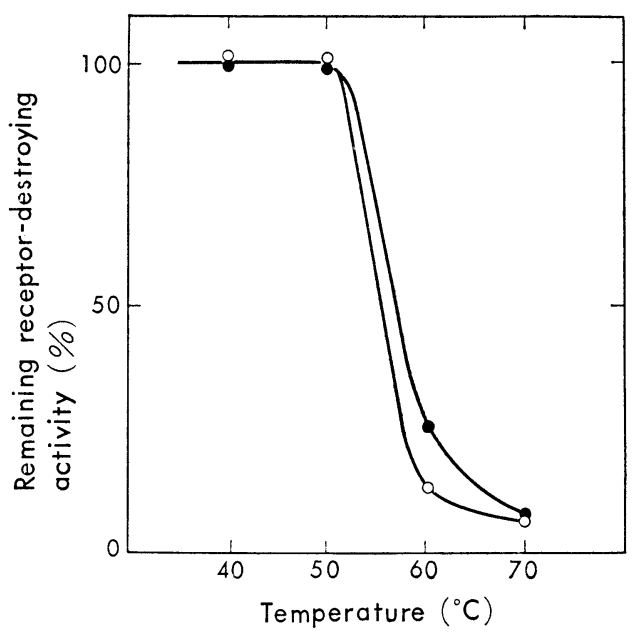

Fig. 3. Heat stability of receptor-destroying activity.

The extract was heated for $3 \mathrm{~min}$ at the required temperature in a water bath and then cooled in ice. Remaining activity was expressed as a percentage of the activity in the unheated control. - $\bigcirc-, 0.025 \mathrm{M}$ citrate phosphate buffer, $\mathrm{pH} 6.2 ;-\bullet-, 0.05 \mathrm{M}$ HCl-glycine buffer, $\mathrm{pH} 2.0$.

There were 2 major peaks with receptor-destroying activity in citrate phosphate buffer, $\mathrm{pH} 6.2$.

\section{DEAE-Cellulose column chromatography}

The major active fractions (tube numbers 90-120, each fraction $4 \mathrm{ml}$ ) from Sephadex chromatography were pooled and dialyzed against $0.01 \mathrm{M}$ Tris$\mathrm{HCl}$ buffer, $\mathrm{pH} 8.0$, and applied to a column $(3 \times 50)$ of DEAE-cellulose, which had been equilibrated with the same buffer. The receptor-destroying factor was eluted with a linearly increasing concentration of $\mathrm{NaCl}$ in this buffer. Effluent was collected in $10-\mathrm{ml}$ fractions (Fig. 5). The receptor-destroying activity at $\mathrm{pH} 6.2$ was further separated by this procedure into several minor peaks.

Receptor-destroying activity at $\mathrm{pH} 6.2$ was further separated by this procedure into several minor peaks.

The major active fractions (tube numbers 115-125) were pooled and dialyzed against distilled water, and its properties were investigated. The partial purification procedure is summarized in Table 1. About 5-fold purification was obtained.

Properties of partially purificd receptor-destroying factor

The $\mathrm{pH}$ dependency of the partially purified factor is shown in Fig. 6 . 


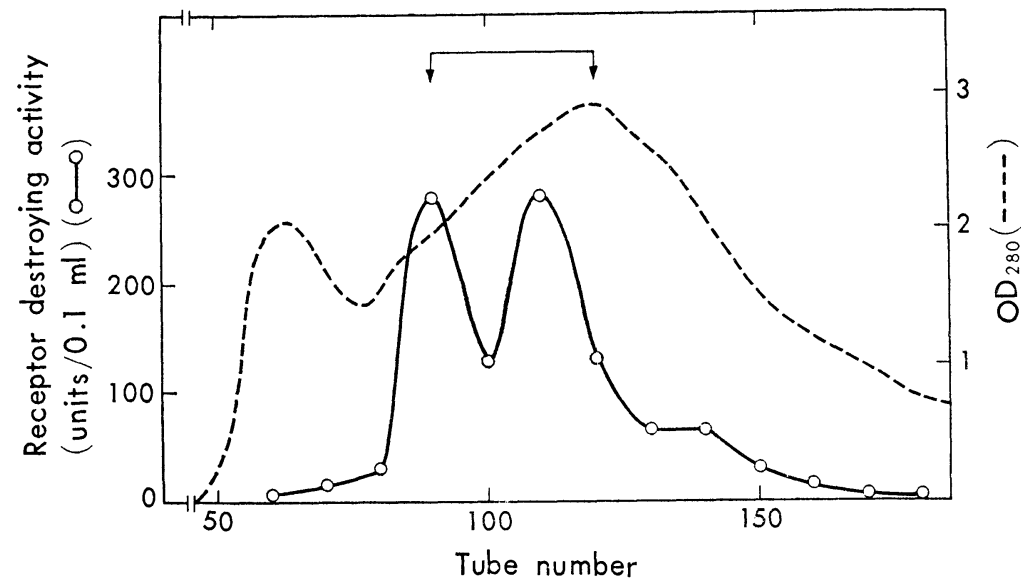

Fig. 4. Sephadex G-200 gel chromatography.

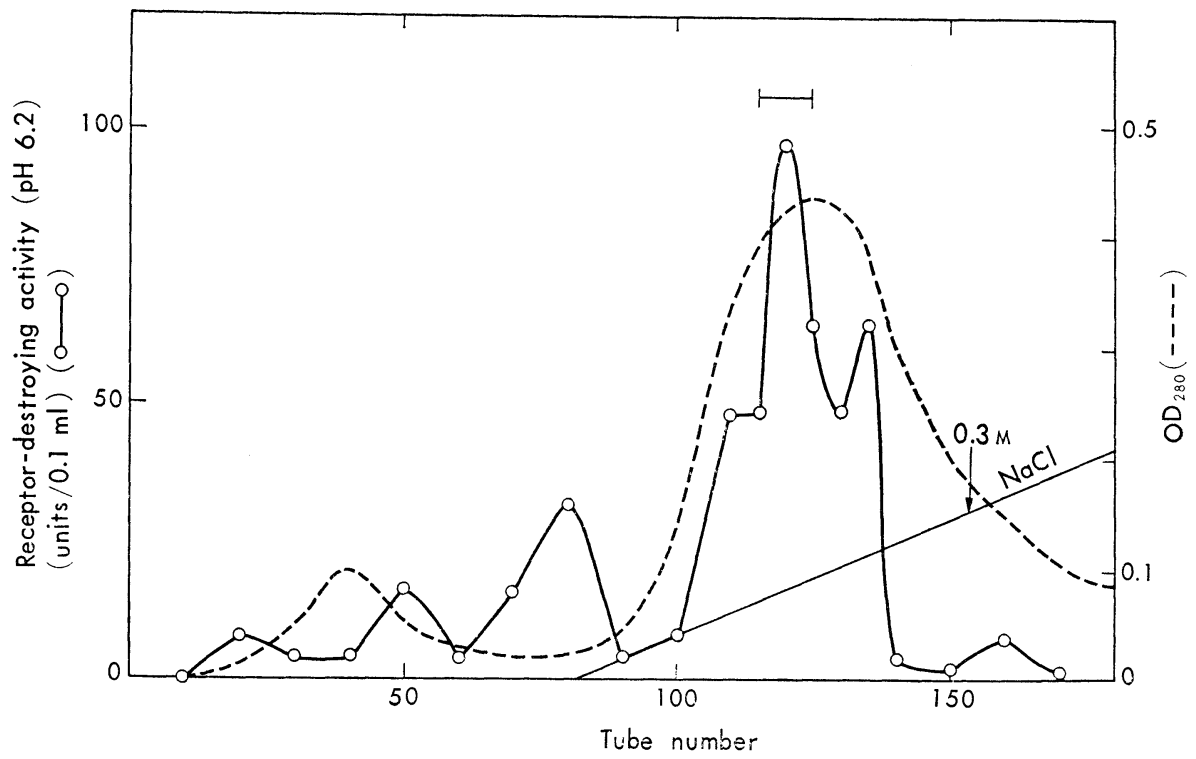

Fig. 5. DEAE-Cellulose column chromatography.

Table 2 shows the effect of $\mathrm{NaCl}$ concentration on the receptor-destroying activity, and Table 3 shows that of $\mathrm{Ca}^{2+}$ and EDTA on the receptor-destroying activity. In the presence of higher concentration of $\mathrm{NaCl}$ or $\mathrm{Ca}^{2+}$, decrease of the receptor-destroying activity was observed. 
Table 1. Purification of receptor-destroying factor from the liver of turbo cornutus.

\begin{tabular}{l|c|c|c|c}
\hline \multicolumn{1}{c|}{ Step } & $\begin{array}{c}\text { Volume } \\
(\mathrm{ml})\end{array}$ & $\begin{array}{c}\text { Protein } \\
(\mathrm{mg} / \mathrm{ml})\end{array}$ & $\begin{array}{c}\text { Activity } \\
\text { (units/ } \\
0.1 \mathrm{ml})\end{array}$ & $\begin{array}{c}\text { Specific } \\
\text { activity } \\
\text { (units/mg } \\
\text { of protein) }\end{array}$ \\
\hline Crude enzyme & 215 & 7 & 256 & 365 \\
Sephadex G-200 column chromatography & 124 & 1.75 & 128 & 731 \\
DEAE-Cellulose column chromatography & 100 & 0.39 & 64 & 1641 \\
\hline
\end{tabular}

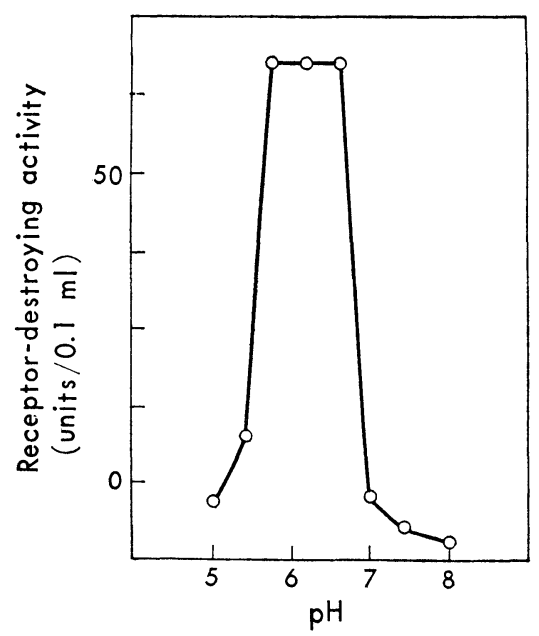

Fig. 6. $\mathrm{pH}$ Dependency of partially purified receptordestroying factor.

This activity was assayed in $0.025 \mathrm{M}$ citrate phosphate buffer.

Table 2. Effect of $\mathrm{NaCl}$ concentration on receptor-destroying activity.

\begin{tabular}{|c|c|c|}
\hline \multicolumn{2}{|c|}{$\mathrm{NaCl}$ conc. } & $\begin{array}{l}\text { Receptor-destroying activity } \\
\text { (units } / 0.1 \mathrm{ml} \text { ) }\end{array}$ \\
\hline \multicolumn{2}{|c|}{ Buffer only } & 64 \\
\hline \multirow[t]{3}{*}{$\mathrm{NaCl}$} & $0.1 \mathrm{M}$ & 16 \\
\hline & $0.5 \mathrm{M}$ & $<4$ \\
\hline & $1.0 \mathrm{M}$ & $<4$ \\
\hline
\end{tabular}


Table 3. Effects of $\mathrm{Ca}^{2+}$ (added as $\mathrm{CaCl}_{2}$ ) on receptor-destroying activity.

\begin{tabular}{|c|c|}
\hline Conc. & $\begin{array}{l}\text { Receptor-destroying activity } \\
\text { (units } / 0.1 \mathrm{ml} \text { ) }\end{array}$ \\
\hline Buffer only & 64 \\
\hline $1 \mathrm{mM}$ & 16 \\
\hline $10 \mathrm{~mm}$ & $<4$ \\
\hline EDTA & 64 \\
\hline
\end{tabular}

\section{DISCUSSION}

In the case of Salmonella lipopolysaccharide, whose chemical nature has been fully investigated, MALCHOW et al. (9) have reported its degradation by an enzyme system in ameba of a cellular slime mold, Dictyostelium discoideum, and they described the nature of the chemical bonds split by the enzyme system.

On the contrary, the chemical nature of the lipopolysaccharide of Pseudomonas aeruginosa has not been fully investigated $(1,7,10-16)$, but the basic architecture seems to be similar to that of Salmonella. The pyocin R-inactivating activity of the lipopolysaccharide was decreased by a liver extract from Turbo cornutus. The extract apparently contained at least two factors attacking pyocin- $\mathrm{R}$ receptor; the one acting below $\mathrm{pH} 4$ destroyed pyocin- $\mathrm{R}$ receptor immediately and the other with $\mathrm{pH}$ optimum at 6.2 destroyed it gradually. We have no idea yet on the chemical mechanism of the receptor destruction. We have not yet succeeded in recognizing the correlation between the receptordestroying activity and the enzyme activities (glycosidases and acetylesterase) of the extract. For the elucidation of the chemical mechanism, further studies are required, both on the chemical nature of the lipopolysaccharide and on the nature of the liver extract.

We wish to thank Dr. M. Kageyama for useful suggestions.

\section{REFERENCES}

1) K. Ikeda and F. Egami, J. Biochem. (Tokyo), 65, 603 (1969).

2) T. Muramatsu and F. Egami, J. Biochem. (Tokyo), 62, 700 (1967).

3) T. Muramatsu, J. Biochem. (Tokyo), 64, 521 (1968).

4) Y. Iijima, T. Muramatsu, and F. Egami, Arch. Biochem. Biophys., 145, 50 (1971).

5) Y. Kurosawa, K. Ikeda, and F. Egami, J. Biochem. (Tokyo), 73, 31 (1973).

6) M. Kageyama, J. Biochem. (Tokyo), 55, 49 (1964).

7) O. Westrhal and K. JAnn, Methods Carbohydrate Chem., 5, 83 (1965).

8) A.H. Fenson and G.W. Gray, Biochem. J., 114, 185 (1969).

9) D. Malchow, O. Lüderitz, B. Kickhöfen, O. WestPhal, and G. Gerisch, Eur. J. Biochem., 7, 239 (1969). 
10) I.R. Chester, G.W. Gray, and S.G. Wilkinson, Biochem. J., 126, 395 (1972).

11) F. Egami, M. Shimomura, H. Ishihara, J.Y. Homma, K. Sagehashi, and S. Hosoya, Bull. Soc. Chim. Biol., 36, 779 (1954).

12) J.Y. Homma, N. Hamamura, M. Naoi, and F. Egami, Bull. Soc. Chim. Biol., 40, 647 (1958).

13) M. Naoi, F. Egami, N. Hamamura, and J.Y. Homma, Biochem. Z., 330, 421 (1958).

14) J.Y. Homma, Z. Allg. Mikrobiol., 8, 227 (1968).

15) K. IkedA and F. EgAmi, J. Gen. Appl. Microbiol., 19, 115 (1973).

15) K. IKedA and Y. Nishi, J. Gen. Appl. Microbiol., 19, 209 (1973). 